\title{
HAS THE AUSTRALIAN PRUDENTIAL REGULATION AUTHORITY DONE ENOUGH TO MEET ITS LEGISLATED OBJECTIVES AND PREPARE AUSTRALIA FOR THE NEXT FINANCIAL CRISIS?
}

\author{
GILL NORTH* AND THERESE WILSON**
}

\begin{abstract}
This article examines APRA's performance against its legislated objectives and the policy rationales and legal theories underlying the supervision of prudential regulation and promotion of financial system stability. The article will investigate the prudential framework in place and actions taken by APRA in the period beginning January 2014 to the end of June 2018, focusing on APRA's oversight of residential property lending standards because the quality of these loans will be the single largest determinant of the future health of the Australian financial system. The current study's findings and broader evidence suggest that APRA's responses to ongoing lax and risky home lending standards were ad hoc, conservative, and reactive.
\end{abstract}

It is in everyone's long-term interest to maintain sound standards when times are good that is, after all, when most bad loans are made. Moreover, sound lending standards are an essential foundation on which the health of the Australian financial system is built. ${ }^{1}$

\section{INTRODUCTION}

In 1997, the Wallis Inquiry into the financial system in Australia ${ }^{2}$ recommended the establishment of a single independent prudential authority and a further independent agency to supervise corporations, market conduct and consumer protection regulation. ${ }^{3}$ Under this 'twin peaks' model, the primary regulators of financial systems and home lending standards and practices in Australia are the Australian Prudential Regulation Authority ('APRA') and the Australian Securities and Investments Commission ('ASIC'). These dual regulators have markedly different roles and focuses. ${ }^{4}$ ASIC has

* $\quad$ BCom CA (NZ); SIE(Dip), ASIA exams (UK); Dip(FS), LLB (Hons), PhD (Aust); Professorial Research Fellow, Law School, Deakin University.

** BA, LLB (Hons), LLM (Advanced), PhD; Associate Professor, Dean of Law and Head of School, Griffith Law School, Griffith University.

1 Wayne Byres, 'Housing: The Importance of Solid Foundations' (Speech, Australian Securitisation Forum 2017, 21 November 2017).

2 Financial System Inquiry Committee, Parliament of Australia, Financial System Inquiry (Final Report, March 1997) ('Wallis Report').

3 Ibid 31, 41, Recommendations 1 and 31 respectively. In 2003, the twin peaks model was strengthened in line with recommendations made by the Royal Commission into the Failure of HIH Insurance.

4 Andrew Godwin and Ian Ramsay, 'Twin Peaks: The Legal and Regulatory Anatomy of Australia's System of Financial Regulation' (Working Paper No 074/2015, Centre for International Finance and Regulation, August 2015). See also Andrew Godwin, Timothy Howse and Ian Ramsay, 'A Jurisdictional Comparison of the Twin Peaks Model of Financial Regulation' (2016) 18(2) Journal of Banking Regulation 103; Andrew Godwin, Guo 
primary responsibility for corporate and financial conduct, ${ }^{5}$ and is the supervisor of the National Consumer Credit Protection Act 2009 (Cth) ('NCCP') and the National Credit Code. The NCCP includes responsible lending regimes among its various consumer credit protections $^{6}$ that are designed to encourage prudent lending, introduce appropriate standards of conduct, ${ }^{7}$ and impose sanctions for irresponsible lending and leasing. ${ }^{8}$ These regimes impose an obligation on all credit providers and credit assistance providers in Australia to ensure a loan is suitable for the borrower (or more precisely, that it is not unsuitable). ${ }^{9}$ The current authors published a review of ASIC's supervision of these responsible lending obligations in 2018, including the responsible lending rules that apply when mortgages are secured on residential property. ${ }^{10}$ This companion article considers APRA's role and its supervision of lending standards and practices.

APRA is the prudential regulator in Australia and is responsible for supervising authorised deposit-taking institutions ${ }^{11}$ ('ADI'), most non-ADI lenders, ${ }^{12}$ insurance businesses, ${ }^{13}$ and superannuation entities other than self-managed superannuation funds. ${ }^{14}$ APRA is required to supervise these various entities in accordance with Commonwealth laws that provide for prudential regulation and retirement income standards. ${ }^{15}$ The legislated objectives of APRA include 'financial safety and efficiency, competition, contestability and competitive neutrality', ${ }^{16}$ with an overarching goal to promote financial system stability in Australia. ${ }^{17}$ APRA establishes principles-based prudential standards to ensure that the institutions it supervises are 'financially sound, well-managed and profitable' 18 and publishes detailed guidance on how its principlesbased standards can be satisfied. ${ }^{19}$

Li and Ian Ramsay, 'Is Australia's "Twin Peaks" System of Financial Regulation a Model for China? (Part 1)' (2016) 46(2) Hong Kong Law Journal 621; Andrew Godwin, Guo Li and Ian Ramsay, 'Is Australia's “Twin Peaks” System of Financial Regulation a Model for China? (Part 2)' (2016) 46(3) Hong Kong Law Journal 935. For an outline of the financial supervisory architectures used internationally, see Daniel Calvo et al, 'Financial Supervisory Architecture: What Has Changed After the Crisis?' (Insights on Policy Implementation No 8, Financial Stability Author, Bank for International Settlements, April 2018).

5 The regulatory scope of ASIC is broad and includes monitoring and supervision of corporations, market operator licensees, and financial service and credit licensees: Australian Securities and Investments Commission Act 2001 (Cth) ss 12A(2), 12A(3).

6 The responsible lending provisions are a sub-set of the various laws designed to protect consumers of credit.

7 Explanatory Memorandum, National Consumer Credit Protection Bill 2009 (Cth) [3.16].

8 Ibid [3.16].

$9 \quad$ National Consumer Credit Protection Act 2009 (Cth) ('NCCP') pts 3-1, 3-2.

10 Gill North and Therese Wilson, 'Supervision of the Responsible Lending Regimes: Theory, Evidence, Analysis and Reforms' (2018) 46(2) Federal Law Review 193. This article was completed and accepted for publication prior to the start of the Royal Commission into Misconduct in the Banking, Superannuation and Financial Services Industry ('Commission').

11 An 'ADI' is defined in s 5 of the Banking Act 1959 (Cth) as 'a body corporate in relation to which an authority under s $9(3)$ is in force'.

12. APRA is empowered to supervise most lenders in Australia, although some forms of lending remain outside of its mandate including entities that provide small amount credit contracts and car loans.

13 APRA is responsible for oversight of the lenders mortgage insurance segment.

14 The Australian Taxation Office has responsibility for excluded self-managed superannuation funds with less than five members.

15 Australian Prudential Regulation Authority Act 1998 (Cth) s 8(1).

16 Ibid s 8(2).

17 Ibid.

18 See, eg, Insurance Act 1973 (Cth) pt IIIA; Banking Act 1959 (Cth) div 1A.

19 John F Laker, 'The Prudential Regulator at Work' (Speech, Australian Institute of Company Directors, NSW Division, 22 March 2006) 2. 
The primary rationale for prudential regulation is to ensure effective management of risk within financial institutions and across the financial system, so that finance supports (rather than disrupts) the real economy and does not harm the communities it serves. ${ }^{20}$ This rationale has been reframed by many policy makers and scholars over the last decade as the promotion of financial stability. Financial system stability is not defined in the Australian Prudential Regulation Authority Act 1998 (Cth) ('APRA Act'). Instead, APRA indicates that its role is 'to promote financial system stability in Australia ... for the benefit of the Australian community' ${ }^{21}$ Internationally, financial stability has been defined as a 'state whereby the build-up of systemic risk is prevented'22 where systemic risk is defined as a 'risk of widespread disruption to the provision of financial services that is caused by an impairment of all or parts of the financial system, and which can cause serious negative consequences for the real economy'. ${ }^{23}$ So, to achieve its objectives, APRA must prevent or constrain the build-up of financial system risks that may disrupt the Australian economy and community. ${ }^{24}$ Systemic risk derives from many sources, including cumulative financial imbalances, large external shocks, and contagion effects across institutions, markets, intermediaries and infrastructure. ${ }^{25}$ The management of financial stability therefore encompasses private and public participants and financial infrastructure, including the legal system and regulatory frameworks for financial regulation, supervision and surveillance. ${ }^{26}$

Since the Global Financial Crisis ('GFC'), a focus on the promotion of financial stability by policy makers and financial supervisors has been singular, with multiple oversight bodies established. Most notably, the Financial Stability Board ('FSB') was set up in April 2009 and is an international body that monitors and makes recommendations about the global financial system. ${ }^{27}$ While its recommendations do not have legal standing, the FSB sets 'internationally agreed policies and minimum standards that its members commit to implement at national level'. ${ }^{28}$ The FSB is acutely aware of the systemic risks caused by inappropriate, unaffordable, and otherwise poor quality residential property lending and the need for sound residential mortgage underwriting standards. ${ }^{29}$ It is through the adoption of the standards and monitoring of

20 See, eg, Australian Prudential Regulation Authority, 'Layers of Safety in the Australian Financial System' (Factsheet No 1, June 2015) 1 ('Layers of Safety'); Harald Benink and Reinhard Schmidt, 'Europe's Single Market for Financial Services: Views by the European Shadow Financial Regulatory Committee' (2004) 1(2) Journal of Financial Stability 157, 159.

21 Australian Prudential Regulation Authority, Submission to Productivity Commission, Productivity Commission Draft Report: Competition in the Australian Financial System (29 March 2018) 4. See also Adam Creighton, 'APRA Keeps Focus on "Stability", The Australian (Canberra, 2 April 2018) 16.

22 European Central Bank, Financial Stability Review (Report, May 2016) 3. See also Garry J Schinasi, 'Defining Financial Stability' (Working Paper No WP/04/187, International Monetary Fund, October 2004).

23 International Monetary Fund, Financial Stability Board and Bank for International Settlements, IMF-FSB-BIS Elements of Effective Macroprudential Policies: Lessons from International Experience (Report, 31August 2016) 4.

24 See North and Wilson (n 10).

25 European Central Bank (n 22) 3.

26 Schinasi (n 22); Australian Government Productivity Commission, Competition in the Australian Financial System (Inquiry Report No 89, 29 June 2018) 73.

27 'About the FSB', Financial Stability Board (Web Page, 2019) <http://www.fsb.org/about/>.

28 'Work of the FSB', Financial Stability Board (Web Page, 2019) <http://www.fsb.org/work-of-the-fsb/>.

29 Financial Stability Board, Thematic Review on Mortgage Underwriting and Origination Practices (Report, 17 March 2011). Mortgage underwriting is the processes lenders use to evaluate loan applications, including the risks of offering a mortgage loan to a borrower: Financial Stability Board, FSB Principles for Sound Residential Mortgage Underwriting Practices (Consultation Paper, 26 October 2011) ('FSB Principles'). 
their ongoing application that sound underwriting practices are sought to be achieved..$^{30}$ As noted by the FSB, 'a robust and effective assessment of individual affordability has to underpin any sustainable lending model $^{\prime 31}$ and highlights the need for strong consumer protections, linking consumer protection to financial stability.

The standards promulgated by the FSB are especially critical in Australia. ${ }^{32}$ Here, more than $60 \%$ of the loans of the largest financial institutions are secured on residential property, ${ }^{33}$ the finance sector is concentrated with more than $82 \%$ of the outstanding ADI home loans issued by the largest four banks, ${ }^{34}$ housing construction is a major driver of economic activity and growth, ${ }^{35}$ and housing and related debt represent the most significant asset and liability of households respectively. ${ }^{36}$ In November 2017 , APRA highlighted the importance of prudential standards to mitigate risk in an environment of high household debt, high house prices, subdued income growth and ... reduced lending standards' ${ }^{37}$ This statement, while accurate, raises obvious questions concerning APRA's regulatory settings and responses that allowed the lending standards to become lax and the levels of household debt to climb to the current levels. APRA confirms that it will not be distracted by calls for it to play a greater role in facilitating competition, and will instead continue to focus on stability of the financial system because of the important community benefits derived from a stable financial system. ${ }^{38}$ APRA's emphasis on the broader community ${ }^{39}$ is appropriate, but raises further critical questions concerning the adequacy of APRA's actions to prevent or constrain the devastation wrought when the next crisis hits.

To assess APRA's performance, we investigate the prudential framework in place and actions taken by APRA in the period beginning January 2014 to the end of June 2018. This timeframe was used because it represents the boom phase of the current residential property cycle and encompasses most of APRA's formal responses to ADIs on home lending standards. The prudential framework of APRA includes the setting of prudential standards, the publication of practice guides, the provision of formal guidance, monitoring and enforcement, and speeches to industry. The APRA website is examined for evidence of formal actions taken by APRA across each of these areas and

30 Financial Stability Board, FSB Principles (n 29) 1.

31 Ibid. See also Financial Stability Board, Consumer Finance Protection with a Particular Focus on Credit (Report, 26 October 2011) 1 which states that 'consumer protection is not about protecting consumers from bad decisions but about enabling consumers to make informed decisions in a marketplace free of deception and abuse', and Gill North, 'Regulation Governing the Provision of Credit Assistance and Financial Advice in Australia: A Consumer's Perspective' (2015) 43(3) Federal Law Review 369 ('A Consumer's Perspective').

32 Wayne Byres, 'Remarks for "The Regulators" Panel' (Speech, A50 Australian Economic Forum, 8 February 2018). Byres confirms that housing represents the largest asset class on the banking industry's balance sheet.

33 Byres, 'Housing: The Importance of Solid Foundations' (n 1).

34 Australian Prudential Regulation Authority, Monthly Banking Statistics: June 2018 (Report, 31 July 2018) Table 2: Loans \& Advances on Australian Books of Individual Companies. These statistics show that the big four banks hold $80.6 \%$ of the outstanding owner occupier loans, $85 \%$ on the investment loans, and $82 \%$ of all home loans issued by ADIs.

35 Philip Lowe, 'Household Debt, Housing Prices and Resilience' (Speech, Economic Society of Australia (QLD) Business Lunch, 4 May 2017). Lowe confirms that the upswing in residential construction activity has substantively supported the Australian economy over recent years.

36 See North and Wilson (n 10).

37 Australian Prudential Regulation Authority, Submission to Productivity Commission (n 201) 4.

38 Ibid. See also Creighton (n 21) 163.

39 Australian Prudential Regulation Authority, Submission to Productivity Commission (n 21) 4, 7. 
activities. $^{40}$ To strengthen our analysis, evidence from the hearings of the Royal Commission into Misconduct in the Banking, Superannuation and Financial Services Industry ('Commission') and other independent sources is also considered, as are the recommendations in the Commission's Final Report.

Our study is motivated by a concern that consumer credit in Australia has grown at levels well above inflation and wages growth for more than twenty years, resulting in record levels of household debt. Philip Lowe, the Governor of the Reserve Bank of Australia, has confirmed that 'recent increases in household debt relative to our income has made the economy less resilient to future shocks' ${ }^{41}$ Even if the housing boom ends with a soft landing, the existing levels of household debt and financial stress will amplify the impact of personal or external shocks on future levels of economic activity, systemic risk and financial stability. ${ }^{42}$ If more severe conditions arise, leading to economic deterioration, there may be significant restrictions on the availability of credit and consequently on consumer spending for many years..$^{43}$

Our study suggests that APRA's responses to the systemic risks arising from the governance and risk management frameworks of lending institutions and the deteriorating mortgage underwriting standards and concerns were reactive, conservative, and incomplete, in the sense that there is no evidence of proactive monitoring of standards leading to detection of breaches or sufficient use of available forensic and enforcement powers. APRA claims that it continuously monitors financial entities to ensure they comply with the prudential standards, are in sound financial condition, and have effective governance and risk management protocols in place. ${ }^{44}$ However, we question the timing, scale, and independence of APRA's monitoring and regulatory interventions. The article contends that APRA's inadequate oversight contributed to an accumulation of systemic risks and that this will cause significant harm to the economy and community when the financial conditions deteriorate. It suggests that APRA's regulatory approach was underpinned by a culture of undue complacency with overtones of possible regulatory capture.

Part II of the article examines APRA's prudential framework, including its formal guidance, prudential standards, powers and enforcement. Part III assesses and critiques APRA's regulatory approach more holistically, including consideration of theoretical explanations for APRA's culture and behaviour. Part IV concludes, noting recommendations in the Commission's Final Report that APRA itself needs to be monitored to ensure its own management accountability. A recommendation for a new oversight authority for APRA is also contained in the APRA Capability Review report released in June 2019.

40 Whilst a prudential regulator communicates with the institutions it oversees at varying levels, including private communication and soft nudges, these informal steps are not captured in our study for evidential reasons. Lowe, 'Household Debt, Housing Prices and Resilience' (n 35). International Monetary Fund, Australia: Selected Issues (Country Report No 18/45, February 2018) 45, 52. Ibid; Gill North, 'Well Governed, Sustainable and Socially Responsible Financial Corporations: Remote or Real Expectations?' in Jean J du Plessis, Umakanth Varottil and Jeroen Veldman (eds), Globalisation of Corporate Social Responsibility and Its Impact on Corporate Governance (Springer, 2018) 27, 29. 


\section{OUR INVESTIGATION OF THE APRA PRUDENTIAL FRAMEWORK AND REGULATORY RESPONSES}

Part II(A) begins with an outline and analysis of the formal guidance provided by APRA to ADIs because we posit that this guidance had the most significant impact on overall prudential and housing loan standards during the study period. This subsection is enriched by inclusion of evidence discussed at the Commission hearings. We then discuss the broader prudential standards in Part II(B), as these standards frame the prudential framework and lending standards in Australia. We complete the study with a review of the enforcement powers of APRA and its utilisation of these powers in Part II(C). More integrated analysis of APRA's regulatory responses is provided in Part III.

\section{A APRA Formal Guidance on Residential Mortgage Lending Standards}

Our study finds evidence of intermittent formal responses by APRA to the finance sector regarding residential mortgage lending standards. Most significantly, APRA highlighted concerns with existing lending standards and practices in three letters sent to ADIs on 9 December 2014, 31 March 2017 and 26 April 2018. These letters are discussed in turn.

\section{December 2014 Letter}

Loans secured on residential property for leasing or investment purposes ('investment home loans') are typically higher risk loans with a greater probability of default than loans on property for the purpose of owner occupation ('owner occupier home loan'). ${ }^{45}$ By the end of 2014, growth in investment home lending in Australia was double digit and comprised around $38 \%$ of outstanding home loans. ${ }^{46}$ This scenario prompted a letter from APRA to all ADIs on 9 December 2014 entitled 'Reinforcing Sound Residential Mortgage Lending Practices'. APRA highlighted the growing pressures on mortgage lending standards resulting from strong competition in the housing market and provided formal guidance on the growth of new investment home loans and the serviceability standards of all home loans. ${ }^{47}$

\section{(a) Investment Home Loans}

In the letter dated 9 December 2014, APRA stated that it would take any growth in mortgage lending to investors above a benchmark of $10 \%$ of total lending activity as an important risk indicator of an ADI. ${ }^{48}$ This growth benchmark of $10 \%$ was characterised as a necessary temporary measure to reduce higher risk lending and improve lending practices.

45 Australian Prudential Regulation Authority, 'Revisions to the Capital Framework for Authorised Deposit-Taking Institutions' (Discussion Paper, 14 February 2018) 18-19. See also Michael Thornley, 'Financial Stability Risks from Housing Market Cycles' (2016) 79(12) Reserve Bank of New Zealand Bulletin 1, 11-12.

46 Reserve Bank of Australia, Submission No 21 to House of Representatives Standing Committee on Economics, Inquiry into House Ownership (June 2015) 19.

47 Letter from Australian Prudential Regulation Authority to All Authorised Deposit-Taking Institutions, 9 December 2014 ('Letter from APRA 9 December 2014'). APRA stated that prudent serviceability policies should incorporate a serviceability buffer of at least $2 \%$ above the loan product rate, with a minimum floor assessment rate of $7 \%$. Note, however, that the serviceability is now likely to be removed: see Joyce Moullakis, 'APRA Reforms to Give Banks a Welcome Boost', The Australian (Canberra, 22 May 2019) 21.

48 'Letter from APRA 9 December 2014' (n 47) 2. Byres indicated in his letter that the guidance was a $10 \%$ benchmark for annual growth in investor lending. See also Byres, 'Remarks for "The Regulators" Panel' (n 32). 
APRA data indicates that growth in outstanding investment home loans for the December to December periods for ADIs with more than 1 billion of term loans, was $12 \%$ in 2014, while the equivalent figures in 2015, 2016 and 2017 were $2 \%, 5 \%$ and $4 \%$ respectively. ${ }^{49}$ Consequently, there was a significant slowdown in new investment loans from 2015 to 2017, with annual growth rates well below the indicative APRA benchmark. However, the total number and outstanding amount of investment home loans continued to increase during the same period, and the serviceability, affordability, and legality of these new loans has been challenged by respected sources, including APRA's chairman, Wayne Byres. ${ }^{50}$

\section{(b) Mortgage Loan Serviceability}

The APRA letter of 9 December 2014 indicated that prudent home lending policies should incorporate a serviceability buffer of at least $2 \%$ above the loan interest rate, meaning that a borrower should have capacity to service an interest rate that is $2 \%$ above the loan interest rate, with a minimum floor assessment rate of $7 \% .{ }^{51}$ Over the course of 2015, APRA monitored the loan serviceability assessments of ADIs using hypothetical test cases. ${ }^{52}$ This exercise asked the largest ADIs to apply their serviceability assessments to four hypothetical borrowers - two owner-occupiers and two investors using their policies in place at 31 December 2014. This 'test' was repeated in late 2015 to see what changes had been made to serviceability assessment models, and APRA reported that ADIs had moved to more prudent standards. ${ }^{53}$ This test case form of monitoring was ad hoc and loosely framed given the scale of the risks and likely consequences.

The hypothetical test results shed no light on whether the models applied by the banks were an accurate reflection of their general home lending standards and practices, particularly in terms of the accuracy of information on which assessments were based. APRA's own data on loan serviceability shows an increasing amount of home loans issued outside of its serviceability standards during the study period. ${ }^{54}$ This data is concerning enough, but likely reveals only the tip of the iceberg in terms of risks embedded within existing loan portfolios. There is mounting evidence of failures by lenders to adequately assess the serviceability of loans in compliance with APRA's prudential standards and formal guidance, failures to assess the affordability of home loans in compliance with the responsible lending rules in the $N C C P,{ }^{55}$ and other forms

49 Australian Prudential Regulation Authority, Statistics: Quarterly Authorised Deposit-Taking Institution Property Exposures (Report, 12 December 2019) Table 1b: ADIs' Residential Property Exposures.

50 Byres, 'Housing: The Importance of Solid Foundations' (n 1); Byres, 'Remarks for "The Regulators" Panel' (n 32). See also Jonathan Mott et al, 'Credit Crunch-ing the Numbers' (UBS Equities Report, 5 April 2018); Jonathan Mott et al, 'UBS Evidence Lab: Liar Loans No 2' (UBS Equities Report, 4 October 2017); JCP Investment Partners, 'Over Capitalised, Over Extended ... LTI Overlooked?' (Investing in Practice, May 2017).

51 'Letter from APRA 9 December 2014' (n 47) 3. See also Australian Prudential Regulation Authority, Statistics: Quarterly Authorised Deposit-Taking Institution Property Exposures (n 49) Table 2c: Banks' New Housing Loan Approvals.

52 'APRA Insight: Issue 1 2016' Australian Prudential Regulation Authority (Web Page, 2016) $<$ https://www.apra.gov.au/apra-insight-issue-1-2016>.

53 Ibid.

54 Australian Prudential Regulation Authority, Statistics: Quarterly Authorised Deposit-Taking Institution Property Exposures (n 49) Table 2c: Banks' New Housing Loan Approvals.

55 See North and Wilson (n 10). 
of lending misconduct. ${ }^{56}$ This evidential base includes admissions made by lenders during the Commission hearings referred to in the section below. Notably and in any event, in an apparent bid to boost the housing market, APRA has now announced consultation with banks regarding a plan to remove the $2 \%$ serviceability buffer. ${ }^{57}$

\section{(c) Commission Evidence on Loan Serviceability and Likely Breaches of APRA's Guidance and the Law}

The possibility of inadequate or inaccurate information on which the serviceability of loans was assessed by the major banks was a feature of the first week of hearings at the Commission from 13 to 19 March 2018.58 William Rankin confirmed to the Commission that he was responsible for Australia and New Zealand Banking Group's ('ANZ') home loan portfolio. He indicated that from October 2016 to September 2017, ANZ issued $\$ 67$ billion in home loans and $56 \%$ of these loans ( $\$ 38$ billion) were arranged through mortgage brokers. ${ }^{59}$ Rankin confirmed that ANZ did not take steps to verify the information provided by brokers regarding customers' expenses. ${ }^{60} \mathrm{He}$ also acknowledged that the bank had not always made genuine enquiries into the living expenses of potential home loan borrowers. ${ }^{61}$

Similarly, Commonwealth Bank of Australia ('CBA') acknowledged inaccuracies in loan application calculations, insufficient documentation and verification of information, and deficiencies in controls around manual loan approval processing in its submission to the Commission. ${ }^{62}$ Daniel Huggins, a supervisor in the home buying division, indicated that although CBA was aware that volume based commissions to brokers encouraged poor quality loans and poor customer outcomes, it continued with this commission structure, and even 'de-accredited' brokers who did not refer a sufficient volume of loans. ${ }^{63}$ Huggins stated that CBA continued to rely on the customer information provided by mortgage brokers, notwithstanding explicit acknowledgment by CBA that customer information provided by brokers could not be relied upon. ${ }^{64}$

Anthony Waldron, the executive general manager for broker partnerships at National Australia Bank ('NAB'), gave evidence regarding NAB's 'Introducer Program'. This program sought introducers that could form relationships with bankers employed by NAB and that could meet minimum loan referral thresholds. Waldron acknowledged that the Introducer Program led to unsuitable loans, false documentation, dishonest application of customers' signatures on consent forms, and misstatements of

56 See, eg, Australian Securities and Investments Commission, 'Lenders to Improve Standards Following InterestOnly Loan Review’ (Media Release 15-220MR, 20 August 2015). See also Australian Securities and Investments Commission, Review of Interest-Only Home Loans (Report No 445, August 2015) ('Report 445'). See Moullakis, 'APRA Reforms to Give Banks a Welcome Boost' (n 47).

58 Michael Roddan, 'APRA Faces Pressure over "Liar Loans”, The Australian (Canberra, 29 March 2018) 20.

59 Transcript of Proceedings, Royal Commission into Misconduct in the Banking, Superannuation and Financial Services Industry (O/N H-871454, Commissioner K Hayne, 19 March 2018) 455 ('Royal Commission Transcript 19 March 2018').

$60 \quad$ Ibid 467

61 Transcript of Proceedings, Royal Commission into Misconduct in the Banking, Superannuation and Financial Services Industry (O/N H-871450, Commissioner K Hayne, 13 March 2018) 38 ('Royal Commission Transcript 13 March 2018').

62 Ibid 42.

63 Transcript of Proceedings, Royal Commission into Misconduct in the Banking, Superannuation and Financial Services Industry (O/N H-871452, Commissioner K Hayne, 15 March 2018) 241-2.

64 Ibid 297-300. 
information in loan documentation. ${ }^{65}$ Both the introducers and bankers benefitted from the loan referrals through bonuses and commissions, and Waldron agreed that the bankers were more concerned with making sales than keeping customers and the bank safe. ${ }^{66}$ Waldron also admitted that neither the introducers nor the bankers were adequately monitored and there were no effective controls to consistently identify intentional misrepresentations of information. ${ }^{67}$

Westpac confirmed in its submission to the Commission that it was the subject of ASIC enforcement action in relation to alleged breaches of the responsible lending obligations, including failures to properly assess whether borrowers could meet their repayment obligations before entering into home loan contracts. ${ }^{68}$ Westpac acknowledged that some of its authorised home lending staff were not correctly verifying customer income and expenses. Several examples of misconduct were discussed, including approval of a loan referral from a mortgage broker for a home loan of $\$ 529,000$ to an 80-year-old man who spoke poor English. ${ }^{69}$

In the third round of hearings between 21 and 25 May 2018, evidence on small business loans secured by residential mortgages was heard. Three of these loans were issued by Westpac. One involved a business loan secured over the residential property of the business borrower's legally blind mother who was in receipt of the disability pension, where it was clear that the bank's concern was the value of the security rather than the borrower's capacity to meet the loan repayments. ${ }^{70}$ Another involved a loan to purchase a store franchise where the estimated cash flow was below the bank's usual benchmark but the value of the residential property security was adequate. ${ }^{71}$ Bank of Queensland similarly approved a loan on the purchase of a business that appeared unsustainable, because the value of the secured property was sufficient. ${ }^{72}$

The evidence deduced by the Commission is damning and reveals poor governance and weak or non-existent risk structures within the relevant lending institutions. These issues were systemic rather than isolated instances. In November 2017, Byres indicated that a recent review of lending files showed a very high proportion of loans were being assessed for serviceability based on living expense benchmarks. ${ }^{73}$ Bank analysts and others indicate that up until late 2017 , between $70-80 \%$ of home loans were underwritten using the Household Expenditure Measure benchmark. This benchmark is

65 Royal Commission Transcript 13 March 2018 (n 61) 77, 83.

66 Transcript of Proceedings, Royal Commission into Misconduct in the Banking, Superannuation and Financial Services Industry (O/N H-871451, Commissioner K Hayne, 14 March 2018) 166-7.

67 Ibid.

68 Royal Commission Transcript 13 March 2018 (n 61) 44.

69 Ibid 44-5. Notably, however, in the judgment handed down by Perram J on 13 August 2019 in the matter of Australian Securities and Investments Commission v Westpac Banking Corporation (Liability Trial) [2019] FCA 1244 , Perram $\mathrm{J}$ found that Westpac had not breached responsible lending provisions by not having regard to borrowers' declared living expenses in its assessments of suitability, and relying on the Household Expenditure Measure benchmark. His Honour found it was enough that declared living expenses were taken into account in applying the $70 \%$ ratio rule where applications were referred for manual processing when declared living expenses exceeded $70 \%$ of verified monthly income. ASIC has lodged an appeal against this decision.

70 Transcript of Proceedings, Royal Commission into Misconduct in the Banking, Superannuation and Financial Services Industry (O/N H-896296, Commissioner K Hayne, 21 May 2018) 2018-59.

71 Transcript of Proceedings, Royal Commission into Misconduct in the Banking, Superannuation and Financial Services Industry (O/N H-896297, Commissioner K Hayne, 22 May 2018) 2176; Transcript of Proceedings, Royal Commission into Misconduct in the Banking, Superannuation and Financial Services Industry $(\mathrm{O} / \mathrm{N}$ H896298, Commissioner K Hayne, 23 May 2018) 2238-46 ('Royal Commissioner Transcript 23 May 2018'). 
estimated based on the state in which the borrower lives, the number of dependent children, and the relevant lifestyle category, with most home mortgages issued assuming the borrower had a 'basic' lifestyle. ${ }^{74}$

In November 2017, Byres further indicated that APRA had identified other significant issues regarding the estimates of borrowers' living expenses, overreliance on less stable sources of income, presumptions that interest rates would remain low, and inadequate enquiries around borrowers' existing debts. ${ }^{75}$ This acknowledgement confirms that APRA was aware of lending practices that constituted poor governance, risky behaviour, and likely misconduct extending well into 2017. If, as Commissioner Hayne suggests, one assumes these practices arose from a trade-off between administrative convenience and applying lending standards, this is 'a very awkward trade-off' ${ }^{76}$ Yet, despite the seriousness of the loan deficiencies identified, there is no evidence that APRA focused on the legal requirement for lenders to collect and verify information on borrower expenses until late April 2018. Moreover, there is no evidence suggesting APRA undertook system-wide reviews of the serviceability, risk, and legality of home loans issued during the study period.

\section{March 2017 Letter}

\section{(a) Interest-Only Home Loans}

The risk of interest-only loans is substantially higher for the relevant lender and borrower than loans that require repayment of the principal and interest on an amortised basis, especially when repayment of the principal at the end of the interest-only period has not been fully accounted for in assessing a borrower's capacity to repay without substantial hardship. In September 2014, a briefings paper from the Reserve Bank of Australia noted that $64 \%$ of home lending to investors had been structured as interestonly loans, with the corresponding share for owner-occupiers at $31 \% .{ }^{77}$ Most of these interest-only loans were for a 5-year period, but some were for an extended duration of 15 years. $^{78}$

In late 2014, ASIC conducted a survey of the interest-only loans segment. ${ }^{79}$ The findings of the survey included a failure on the part of many lenders to properly assess suitability of loans to meet borrowers' needs, or to assess the borrowers' capacity to repay without hardship. It also found that there was substantial variation in the way lenders applied interest rate buffers. There were found to have been systemic failures

74 Mott et al, 'Credit Crunch-ing the Numbers' (n 50) 3. The statistic of 70-80\% was confirmed by ANZ in the Commission hearings: Royal Commission into Misconduct in the Banking, Superannuation and Financial Services Industry (Interim Report, September 2018) vol 2, 44-5.

75 Byres, 'Housing: The Importance of Solid Foundations' (n 1).

76 Royal Commission Transcript 19 March 2018 (n 59) 466.

77 Reserve Bank of Australia, 'Briefing on Macroprudential Options for Housing Lending' (Briefing Note, 26 September 2014) 1. This briefing note was sought under the Freedom of Information Act 1982 (Cth) and was subsequently publicly released by the Reserve Bank of Australia.

78 Reserve Bank of Australia, 'Briefing on Macroprudential Options for Housing Lending' (n 77) 2.

79 See Australian Securities and Investments Commission, Review of Interest-Only Home Loans (n 56); Australian Securities and Investments Commission, 'Lenders to Improve Standards Following Interest-Only Loan Review' ( $\mathrm{n}$ 56). An industry study found that there was substantial variation in the way lenders applied interest rate buffers. On pages 48-51 of Report 445 (n 56), ASIC discusses the ability of consumers with interest-only loans to service their loans, including the buffers allowed for interest rate rises. ASIC refers to the APRA guidance that advises lenders to apply a minimum interest rate buffer of at least $2 \%$ and a minimum floor rate of $7 \%$. It emphasises the need for more caution when the lenders have used a benchmark for estimating the expenses of a borrower and when the surplus calculated for a borrower's financial situation is low. 
on the part of lenders to take into account customers' actual expenses, or their capacity to repay the loan principal and cope with interest rate rises. ${ }^{80}$

The APRA guidance that required lenders to limit growth in new investment home loans to $10 \%$ indirectly dampened growth in interest-only home loans, and the linkage between these loan segments is reflected in the APRA data. The December to December year-on-year growth in outstanding interest-only loans by large ADIs was $21 \%$ in 2014 , but $11 \%$ in 2015 and $7 \%$ in $2016 .{ }^{81}$ Nonetheless, the overall share of interest-only home loans remained persistently high. At the end of 2015 and 2016, interest-only loans still comprised $39 \%$ of outstanding loans of large ADIs, and this prompted a belated response by APRA.

In a letter to ADIs dated 31 March 2017, APRA noted that 'the environment remains one of high housing prices, high and rising household indebtedness, subdued household income growth, historically low interest rates and strong competitive pressures' ${ }^{82}$ Given these risks, APRA indicated that it expected ADIs to limit new interest-only residential mortgages to $30 \%$ of total new home lending. This APRA guidance was effective within its specified terms, as the share of these loans fell to $33 \%$ by the end of $2017 .{ }^{33}$ However, the benchmark of $30 \%$ interest-only loans is well above other jurisdictions, ${ }^{84}$ leaving some lenders and many of the borrowers heavily exposed to adverse circumstantial changes. In a survey of interest-only home loan borrowers in mid-2017, 35\% indicated they were in moderate stress, while $36 \%$ were under high stress. ${ }^{85}$ Segmental analysis of proprietary data held by Digital Finance Analytics ('DFA') suggests Australian households with an interest-only loan that are in financial stress include young families buying their first home and more affluent households with one or more investment properties. ${ }^{86}$

\section{April 2018 Letter}

On 26 April 2018, APRA indicated by letter to ADIs that it would remove the $10 \%$ benchmark on mortgages for investment purposes where the board of an ADI could demonstrate to APRA that their investment home loans were below the $10 \%$ growth level for the prior six months, their lending policies met APRA's prior guidance on serviceability, and their lending practices would be strengthened if necessary. ${ }^{87}$ APRA stated that the temporary benchmark had served its purpose because investment home

80 Australian Securities and Investments Commission, Review of Interest-Only Home Loans (n 56) 57-66.

81 Australian Prudential Regulation Authority, Statistics: Quarterly Authorised Deposit-Taking Institution Property Exposures (n 49) Table 1b: ADIs' Residential Property Exposures.

82 Letter from Australian Prudential Regulation Authority to all Authorised Deposit-Taking Institutions, 31 March 2017, 1 .

83 Australian Prudential Regulation Authority, Statistics: Quarterly Authorised Deposit-Taking Institution Property Exposures (n 49) Table 1b: ADIs' Residential Property Exposures.

84 For example, as at 2016, the proportion of investor housing loans in the United Kingdom was around $17 \%$ and the authorities there were concerned about the risks associated with these loans: see Bank of England, Financial Stability Report (Report No 39, July 2016) vi-vii, 13.

85 Mott et al, 'UBS Evidence Lab: Liar Loans No 2: Interest Only' (n 50) 1.

86 See Elizabeth Knight, 'Not in Their Interest: The Home Loan Borrowers that Have Been Left Out to Dry', The Sydney Morning Herald (online, 23 June 2017) <http://www.smh.com.au/business/banking-and-finance/not-intheir-interest-the-home-loan-borrowers-that-have-been-left-out-to-dry-20170623-gwx2dn.html>.

87 Letter from Australian Prudential Regulation Authority to all Authorised Deposit-Taking Institutions, 26 April 2018 ('Letter from APRA 26 April 2018') 1-2. See also Australian Prudential Regulation Authority, 'APRA Announces Plans to Remove Investor Lending Benchmark and Embed Better Practices’ (Media Release, 26 April 2018). 
loan growth had moderated, interest-only loans were declining, and lending standards had improved. ${ }^{88}$

The required assurances from an individual lender to prompt APRA to remove the investment home loan growth benchmark included a commitment to collect information on borrowers' actual expenses and reduce reliance on benchmark estimates. ${ }^{89}$ The lateness of explicit guidance on this compliance area is remarkable, given APRA's internal reviews had highlighted sector wide reliance on expense benchmarks and several legal actions had confirmed the need for lenders to collect and verify borrower income and expense data. ${ }^{90}$ One can surmise that APRA included this commitment following the strong focus by the Commission on this legal obligation.

The assurances sought by APRA further require lenders to verify the existing debt commitments of a borrower and to develop internal risk limits on the proportion of lending where debt is greater than six times a borrower's income. These requirements were the first signal by APRA to lenders that they should consider the overall financial position of borrowers, including their total borrowings, rather than merely their capacity to repay a specific loan. This signal represented a critical but overdue change in regulatory direction.

In November 2017, Byres highlighted that high loan-to-income ('LTI') lending (the size of the relevant loan divided by the income of the borrower) in Australia was well north of what is permitted in other jurisdictions. ${ }^{91}$ For example, in the United Kingdom, new lending with LTI ratios of 4.5 times or greater is limited to $15 \%$ of new residential mortgages. And in Ireland, new lending with an LTI of 3.5 times or greater is limited to $20 \%$ of the total number of new residential mortgages..$^{92}$ In contrast, Australian lenders were not required to collect or report LTI data to APRA during the study period, despite the relative ease of calculating this when a loan is issued..$^{33}$

A debt-to-income assessment (most commonly, the total debt of a borrower divided by their total gross income) is a more complex but critical indicator of the serviceability (and affordability) of a loan than the LTI metric because it encompasses all the debts owed by the borrower, including possible multiple home loans, credit cards, and personal loans. Byres admitted in April 2018 that the other debt and financial commitments of mortgage borrowers remained a 'blind spot for lenders' ${ }^{94}$ APRA and others hope that the introduction of mandatory comprehensive credit reporting from

88 Letter from APRA 26 April 2018 (n 87). Despite APRA's optimistic tone in the letter to ADIs, a media release issued the same day indicated that the environment remained one of heightened risk: Australian Prudential Regulation Authority, 'APRA Announces Plans to Remove Investor Lending Benchmark and Embed Better Practices' (n 87).

89 Letter from APRA 26 April 2018 (n 87) 3-4.

90 See, eg, Australian Securities and Investments Commission v The Cash Store Pty Ltd (in liq) [2014] FCA 926; Australian Securities and Investments Commission, 'ASIC Concerns Prompt Bank of Queensland to Improve Lending Practices' (Media Release 15-125MR, 25 May 2015); Australian Securities and Investments Commission, 'ASIC Commences Civil Penalty Proceedings against Westpac for Breaching Home-Loan Responsible Lending Laws' (Media Release 17-048MR, 1 March 2017), although note the finding of Perram J in the judgment handed down on 13 August 2019 in the matter of Australian Securities and Investments Commission v Westpac Banking Corporation (Liability Trial) [2019] FCA 1244; Australian Securities and Investments Commission v Australia and New Zealand Banking Group Limited [2018] FCA 155.

91 Byres, 'Housing: The Importance of Solid Foundations' (n 1).

92 Ibid.

93 Australian ADIs have been required to provide data to APRA on the ratio of term loans with loan to income ratios above four times since February 2018, but this data is only for new loans: Australian Prudential Regulation Authority, Reporting Standard ARS 223.0: Residential Mortgage Lending (February 2018) 22-3. Byres, 'Housing: The Importance of Solid Foundations' (n 1). 
July 2018 will address this deficiency. ${ }^{95}$ But even if this reporting process operates as many expect, the data on the debts of existing mortgage borrowers will be limited to information collected in the loan applications and otherwise by lenders at the time a loan is issued and will not benefit from comprehensive credit reporting.

Residential property loans now comprise more than four to five times gross household income, ${ }^{96}$ average household debt to disposable income is around $186.6 \%,{ }^{97}$ and more than $30 \%$ of households are in financial stress. ${ }^{98}$ The sustainability of these levels of household debt and the impact of the debt on the Australian economy and community are contested. ${ }^{99}$ Credible analysis requires detailed knowledge regarding the distribution of the debt across the population and the overall financial position of individual or household borrowers, including their total debt, assets, savings, income and expenses. Those carrying the most debt are most likely to be without savings. ${ }^{100}$ This is unsurprising given the rising levels of inequality and wealth, ${ }^{101}$ stagnant wages, ${ }^{102}$ widespread use of part time and casual employment, and high housing costs in Australia. ${ }^{103}$ These combined factors are exacerbating the financial pressures on households, despite the still relatively benign economic settings. For an increasing number of households the consequences of changes to interest rates, real estate values and employment conditions could be significant, and certainly the consequences of a financial crisis could be devastating. ${ }^{104}$

DFA holds data that is collected through regular surveys of Australian households. ${ }^{105}$ This data shows that within the owner occupier loan portfolios, the

95 Byres, 'Remarks for "The Regulators" Panel' (n 32).

96 International Monetary Fund, Australia: Selected Issues (n 42) 44.

97 Reserve Bank of Australia, 'Household and Business Finances: Selected Ratios' (Statistical Table E2, September 2019) <https://www.rba.gov.au/statistics/tables/>.

98 As at June, DFA measures and tracks levels of household financial stress in Australia based on the cashflow of a household (including its income, outgoings, and debt repayments): 'Household Finance Confidence Index', Digital Finance Analytics (Blog) <https://digitalfinanceanalytics.com/blog/tag/household-finance-confidenceindex/> See also ME Bank, Household Financial Comfort Report (Report No 15, February 2018) 19. The ME survey indicates that $42 \%$ of households surveyed reported that they 'will not be able to meet their required minimum payments on their debt' or 'can just manage to make minimum payments on their debt' in the next 612 months.

99 See, eg, JCP Investment Partners (n 50); Jonathan Mott and Rachel Bentvelzen, 'Overstated Income Raises Mortgage Mis-Selling Risk' (UBS Equities Report, 5 February 2018); North and Wilson (n 10); cf Michael Pascoe, 'Why Household Debt is Not as Scary as Generally Claimed', The New Daily (online, 24 July 2018) $<$ https://thenewdaily.com.au/money/finance-news/2018/07/24/household-debt-overstated/>. Pascoe discusses total net debt figures without considering the positioning of cash buffers across the population.

100 See Axelle Marjolin et al, 'Why Is Financial Stress on the Rise? Financial Resilience in Australia 2016' (Report, Centre for Social Impact, National Australia Bank, September 2017) 9, 22. A survey by the Centre for Social Impact and $\mathrm{NAB}$ found that $31.6 \%$ of respondents had either no savings or less than a month of savings.

101 Australian Government Productivity Commission, 'Rising Inequality? A Stocktake of the Evidence' (Research Paper, August 2018) 74-5.

102 Philip Lowe, 'Resilience and Ongoing Challenges' (Speech, Urban Development Institute of Australia National Congress, 8 March 2016).

103 See, eg, Evidence to House Standing Committee of Economics, Parliament of Australia, Canberra, 24 February 2017, 2-3, 14-15 (Philip Lowe).

104 See, eg, Financial System Inquiry Committee, Parliament of Australia, Financial System Inquiry (Final Report, November 2014) 33, 43-4, 47 ('Murray Report'). See also Financial System Inquiry Committee, Parliament of Australia, Financial System Inquiry (Interim Report, July 2014) 2-57; Thornley (n 45).

105 DFA proprietary data at end of December 2017. DFA is a boutique research, analysis and consulting firm providing commercial services to clients in Australia and internationally. It maintains industry models, authors 
average LTI ratio of households as at 15 August 2018 is 3.51 and the average debt-toincome ratio is 4.70. More worryingly, the average household LTI ratio on loans issued over the last twelve months is 5.12 and the average debt-to-income of these borrower households is 6.16. ${ }^{106}$ The average investment home loan portfolio statistics are similar to those for owner occupiers. However, the average LTI ratio of households with an investment loan issued in the last twelve months is 5.83 and the average debt-to-income of these borrowers is 8.21. ${ }^{107}$ Thus, the proportion of loans above the LTI benchmarks in the UK and Ireland is significantly higher than the respective 15-20\% limits. Furthermore, of the Australian households with a home loan, 19.1\% have a debt-toincome ratio above six.

\section{B APRA Prudential Standards}

APRA issues Australian Prudential Standards ('APS') that establish the key parameters of the prudential framework in Australia, including the capital adequacy rules and determinants of credit quality. These rules reflect the international Basel capital standards, with some adjustments for local conditions. The Basel capital standards seek to ensure soundness and stability in international banking, ${ }^{108}$ through requiring that a financial institution's capital is adequate to meet its risks. Asset risks are determined by tiered risk weightings that adjust capital requirements linked to the relevant assets. The adequacy of a bank's capital and its home lending standards are closely linked, because losses resulting from loan defaults reduce its capital base, and in severe conditions can deplete its capital entirely. The Basel Committee recognises these risks, and in January 2010 recommended improved oversight of the residential mortgage market, including greater consistency in underwriting standards. ${ }^{109}$

In Australia, APS 110 requires ADIs to maintain required levels of regulatory capital, to inform APRA of any adverse change in actual or anticipated capital adequacy, and to seek APRA's approval for any planned capital reductions. ${ }^{110}$ APS 111 sets out the characteristics for an instrument to qualify as either Tier 1 or Tier 2 regulatory capital. ${ }^{111}$ APS 112 deals with risk weightings under the 'standardised approach' to capital adequacy that applies to ADIs that do not qualify for an internal ratings-based approach. ${ }^{112}$ APS 113 allows qualified ADIs to adopt an 'internal-ratings based approach' to assess credit risk and to determine capital adequacy requirements,

various finance industry reports, and collaborates with large financial institutions to provide regular mortgage, housing sector, small and medium sized business publication series.

106 DFA proprietary data as at 15 August 2018.

107 The loan-to-income ratio is the value of the investment loan to gross rental income. The debt-to-income ratio is the total amount of all loans to total gross income, including wages and rents etc.

108 See, eg, Bank for International Settlements, International Convergence of Capital Measurement and Capital Standards: A Revised Framework (10 June 2004) [4] <https://www.bis.org/publ/bcbs107.htm>.

109 The Joint Forum (Basel Committee on Banking Supervision, International Organization of Securities Commissions, International Association of Insurance Supervisors), Review of the Differentiated Nature and Scope of Financial Regulation: Key Issues and Recommendations (Review, January 2010) ch 3.

110 Australian Prudential Regulation Authority, Banking (Prudential Standard) Determination No 4 of 2015 : Prudential Standard APS 110 Capital Adequacy (1 January 2016).

111 Australian Prudential Regulation Authority, Banking (Prudential Standard) Determination No 4 of 2017 : Prudential Standard APS 111 Capital Adequacy (1 January 2018).

112 Australian Prudential Regulation Authority, Banking (Prudential Standard) Determination No 2 of 2018 : Prudential Standard APS 112 Capital Adequacy (1 July 2019). 
subject to APRA approval. ${ }^{113}$ APS 114 requires ADIs to divide their business into retail banking, commercial banking and other activities, and apply varying capital requirements depending on the relevant business risks. ${ }^{14}$ APS 220 requires ADIs to control credit risk by adopting prudent credit risk management policies and procedures. ${ }^{15}$ The ensuing discussion focuses on APS 112 and APS 220 because these standards are especially critical when discussing APRA's approach to promote financial system stability in Australia.

\section{APS 112}

APRA conducted stress tests during the first half of 2018 to assess the capital adequacy of the banking sector, with the scenarios tested including adverse economic and financial settings. ${ }^{116}$ APRA concluded that the capital held by the sector would be sufficient to withstand a relatively severe scenario. ${ }^{117}$ However, the extent to which APRA independently supervised and assessed the lenders running the stress test models, and the reliability of the data sets and assumptions used, is unknown. In any event, stress testing is an inexact science and the harm caused by contagion and the sectoral interconnections are difficult to predict and assess. ${ }^{118}$ It is these contagions or secondorder factors that were massively underestimated prior to the GFC and these factors are likely to be similarly underestimated in the APRA model given the importance of residential property to the finance sector and economy. ${ }^{119}$

113 Australian Prudential Regulation Authority, Banking (Prudential Standard) Determination No 6 of 2012: Prudential Standard APS 113 Capital Adequacy (1 January 2013). See Timothy A Canova, 'Financial Market Failure as a Crisis in the Rule of Law: From Market Fundamentalism to a New Keynesian Regulatory Model' (2009) 3(2) Harvard Law and Policy Review 369, 381; Jeffery Atik, 'Basel II and Extreme Risk Analysis' (Legal Studies Paper No 2010-40, Loyola Law School, 26 February 2009). Canova points out that prior to the GFC, 'the banks ... had every incentive to under-measure the risk of their assets, and thereby keep less capital in reserve': Canova (n 113) 381.

114 Australian Prudential Regulation Authority, Banking (Prudential Standard) Determination No 7 of 2012 : Prudential Standard APS 114 Capital Adequacy (1 January 2013).

115 Australian Prudential Regulation Authority, Banking (Prudential Standard) Determination No 8 of 2014: Prudential Standard APS 220 Credit Quality (1 January 2015).

116 See, eg, Wayne Byres, 'APRA Chair Wayne Byres: Speech to the Australian Business Economists' (Speech, Australian Business Economists, 10 July 2018). The assumptions made by APRA in its most severe model setting included: 'a downturn in China and a collapse in demand for commodities'; a 'subsequent downgrade in sovereign and bank debt ratings [leading] to a temporary closure of offshore funding markets'; 'a selloff in the Australian dollar and widening in credit spreads'; a fall of $4 \%$ in the Australian gross domestic product; unemployment doubles to $11 \%$; house prices decline by $35 \%$ nationally over three years. The plausibility of these assumptions is challenged by commentators: see, eg, 'Putting APRA's Stress Test to the Test', $L F$ Economics (Web Page, 12 July 2018) <www.lfeconomics.com/analysis/putting-apras-stress-test-test/> ('Putting APRA's Stress to the Test'); John Adams, 'APRA Airbrushes Australian History to Avoid Economic Armageddon', As Good as Gold Australia (Blog Post, 21 July 2018)

$<$ http://www.asgoodasgoldaus.com.au/blog/apra-airbrushes-australian-history-to-avoid-economicarmageddon/>. LF Economics concludes that 'there is simply no way Australian banks would ever survive APRA's implied elements ... once you factor in the further losses outside of retail banking in real life': 'Putting APRA's Stress to the Test' (n 116). Adams points out that Australia's record household debt to disposable income levels are occurring within a global economy with record debt levels. He indicates that the only plausible setting that would support APRA's assumed model $4 \%$ fall in gross domestic product would involve unprecedented levels of stimuli and support from the Australian and foreign governments, and the world's central banks: Adams (n 116).

117 Byres, 'APRA Chair Wayne Byres: Speech to the Australian Business Economists' (n 116).

118 Wallis Report (n 2) 47.

119 See Canova (n 113) 381. Canova notes that 'economists and policymakers failed to learn from history that their risk models were unrealistic'. 
The Financial System Inquiry recommended that the minimum ADI capital levels in Australia be raised to 'unquestionably strong' levels. ${ }^{120}$ Despite APRA's conclusion that current levels of capital are adequate, it issued a discussion paper in February 2018 with proposed amendments to APS 112 that involve major changes to the standardised approach to credit risk and the capital adequacy requirements to meet that risk. ${ }^{121}$ Under these proposals, residential mortgages would be segmented into categories, with the capital requirements reflecting the associated risk. The three mortgage loan categories would be: (1) 'loans meeting serviceability requirements made to owner-occupiers where ... repayment is on a principal and interest (P\&I) basis'; (2) 'loans ... for investment purposes or ... [structured] on an interest-only basis' that meet serviceability requirements; and (3) 'other residential property exposures'. ${ }^{122}$ For the category one loans, APRA proposes to closely align the risk weights to those in the Basel II framework where the repayments are not dependent on net cashflows generated by the secured property such as rental receipts. The key objectives of the proposed changes are to address the systemic concentration of the ADIs' residential mortgage portfolios and the riskiness of large segments of these portfolios, including investment home loans, interest-only home loan, and home loans that do not meet minimum serviceability requirements.

APS 112 currently defines 'standard eligible residential mortgages' (standard mortgages) as those that meet serviceability, marketability and valuation criteria. ${ }^{123}$ APRA plans to update APS 112 to incorporate the Basel III changes, with risk weights for standard mortgages primarily based on loan-to-valuation ratios. Importantly though, it also proposes to alter the serviceability parameters and require ADIs to deem mortgages as 'non-standard' when the ADI: (1) 'did not include an interest rate buffer of at least two percentage points and a minimum assessment interest rate of at least seven per cent' in its serviceability criteria when approving the loan; (2) 'did not verify that a borrower' can repay the loan (including the principal and interest) on a net income basis; and (3) 'approved the loan outside the ADI's loan serviceability policy'. ${ }^{124}$ Other mortgages that APRA proposes to designate as non-standard within APS 112 include loans to self-managed superannuation funds secured by residential property and reverse mortgages. ${ }^{125}$ APRA is also considering whether to deem mortgages as non-standard where the LTI multiples are very high. Another aspect of APS 112 to be reviewed is the treatment of small business loans secured by residential property. Currently loans to small medium enterprises, defined by APRA as businesses with annual group sales of less than $\$ 50$ million, receive the same capital treatment as other loans secured by residential property. ${ }^{126}$ APRA proposes to change the risk weighting of these home loans

120 Wallis Report (n 2) 23.

121 Australian Prudential Regulation Authority, 'Revisions to the Capital Framework for Authorised Deposit-Taking Institutions' (n 45).

122 Ibid 6. See also Joyce Moullakis, 'APRA to Target Risky Home Loans', The Australian (Canberra, 13 June 2019) 25.

123 Australian Prudential Regulation Authority, 'Revisions to the Capital Framework for Authorised Deposit-Taking Institutions' (n 45) 22. The APRA discussion paper notes that this definition largely aligns with the Basel III operational requirements. Ibid.

125 Ibid.

126 Australian Prudential Regulation Authority, 'The Regulatory Capital Framework for Authorised Deposit-Taking Institutions' (Background Paper No 9, April 2018) 7, 11. This paper was prepared in response to a request from the Commission. 
to equate to those that apply to interest-only home loans and investment home loans. ${ }^{127}$ APRA indicates that capital requirements will continue to be lower for mortgages covered by loan mortgage insurance. ${ }^{128}$

The aims and structure of APRA's capital proposals align well with global evidence on residential property lending risks and Australian conditions. However, if adopted, these capital settings will have major implications for the banking sector, home loan borrowers, small businesses, and ultimately the nation. APRA's proposals raise several issues. First, these settings should have been applied earlier to ensure the underwriting standards of home mortgages were more appropriate during the boom period and reflected the true risks involved. Second, adoption of the proposal in full is likely to be vigorously opposed by industry because it would effectively apply the prior APRA guidance retrospectively to continuing loans. Third, the revised structure would penalise lenders that issued mortgages prior to publication of the APRA guidance on interest rate buffers and would retrospectively apply specific borrower repayment and LTI criteria that have not yet been agreed.

\section{APS 220}

Under APS 220, a loan facility must be classified as impaired when there is doubt about the likely repayment of the full amount due, including interest and other payments, in a timely manner. ADIs are required to document and implement sound policies and procedures and to apply experienced credit judgment in order to recognise matters that might reasonably suggest that a party to a facility, including a loan facility, may be unlikely to meet its contractual obligations. APS 220 effectively requires an ADI to control credit risk by adopting prudent credit risk management policies and procedures.

APRA prudential practice guide ('APG') 223 is designed to be read in conjunction with APS 220 and outlines prudent practices in the management of risks arising from loans secured by mortgage over residential properties (including owner-occupied and investment home loans). APG 223 highlights the importance of strong loan origination criteria to mitigate credit risk. It indicates that a prudent ADI would consider the different profiles of loans when assessing risk, including whether the loans are principal and interest or interest-only, and whether the loans are for owner-occupied or investment properties. ${ }^{129}$ ADIs are advised to undertake sound credit risk management, including accurate '[assessment] of a borrower's ability to service and ultimately repay a loan without undue hardship' ${ }^{130}$ APG 223 further requires a lender to align its policy and procedures 'with the changing external environment', such as the possibility of interest rate rises and housing price collapses. ${ }^{131}$ The guidance in APG 223 is sound, but the evidence discussed earlier suggests many lenders issued loans during the study period without properly assessing credit risk, without allowing adequate serviceability buffers for borrowers to continue repaying their loans when interest rates increase or

127 Ibid 9.

128 In Australia, loan mortgage insurance is generally paid by mortgagees with loan-to-value ratios of $80 \%$ or more. This insurance is designed to provide the lender with last resort protection when the assets of the borrower including sale of the secured property are insufficient to cover the loan costs. For further information, see Gill North, 'A Consumer's Perspective' (n 31).

129 Australian Prudential Regulation Authority, Prudential Practice Guide: APG 223 (Guide, February 2017) 6 [5].

130 Ibid 11 [25].

131 Ibid. 
the equity in their property decreases, and without adequate consideration of borrowers' capacity to repay their loans.

Page 16 of APG 223 discusses the obligations of a lender when loans are referred by brokers and indicates that

[i]n circumstances where third parties (such as a mortgage broker) accept or complete applications, but have no ability to approve a residential mortgage loan, a sound oversight process is necessary. In particular, a prudent ADI would have appropriate procedures in place to verify the accuracy and completeness of the information provided. ${ }^{132}$

This commentary is especially pertinent when considering the alleged and conceded failings highlighted by the Commission. Some of the most egregious conduct involved home loan intermediaries (defined as 'credit assisters' under the $N C C P$ ) ${ }^{133}$ with failures by these persons or entities to obtain and verify borrower information, and subsequent corresponding failures by the credit providers.

\section{APRA's Powers and Enforcement Record}

Since 2004, APRA has adopted a risk-based regulatory framework, where the form of regulation applied to an entity is determined by the risk that entity poses to APRA's regulatory objectives. ${ }^{134}$ This framework incorporates a Probability and Impact Rating System ('PAIRS') and a Supervisory Oversight and Response System ('SOARS').135 PAIRS is used to assess the risk level of an entity against the regulatory objectives of APRA and allocates a risk score. The SOARS system is used to categorise APRA's response to that risk ${ }^{136}$ as either '[n]ormal', '[o]versight', '[m] andated improvement', or '[r]estructure'. ${ }^{137}$ These combined systems were introduced in response to criticisms of APRA following the collapse of general insurance company, HIH, in March 2001. It was suggested at that time that APRA had been guilty of missing warning signs and overestimating the levels of sophistication and internal controls in the insurance industry. ${ }^{138}$

APRA has considerable powers that it can wield against lenders, including specific powers to establish prudential standards, conduct forensic investigations, direct corrective actions, and disqualify individuals from positions of responsibility. ${ }^{139}$ APRA's powers derive from the APRA Act and the various statutes that it administers, such as the Banking Act 1959 (Cth) ('Banking Act'). For example, under division 2C of the Banking Act, APRA has the power to enter into enforceable undertakings with ADIs, and under division 3 of the same statute, APRA may apply to the Federal Court for a disqualification order against a person with a prudentially significant role in an ADI.

132 Ibid 16 [53].

133 Discussions with a potential borrower about the provision of credit by a licensed credit intermediary (or an employee or representative of the intermediary) or a licensed entity that provides credit (or an employee or representative of the entity) may fall within the responsible lending provisions: NCCP pts 3-1, 3-2.

134 See discussion in Julia Black, 'Managing Regulatory Risks and Defining the Parameters of Blame: A Focus on the Australian Prudential Regulation Authority' (2006) 28(1) Law and Policy 1, 4 ('Managing Regulatory Risks').

135 Ibid 2.

136 Ibid 8.

137 Australian Prudential Regulation Authority, Supervisory Oversight and Response System (Report, April 2017 ) 5.

138 Black, 'Managing Regulatory Risks' (n 134) 6-7.

139 APRA's powers were enlarged by the introduction of the Bank Executive Accountability Regime, but these rules did not take effect until 1 July 2018. 
The disqualifications register on APRA's website lists only one action against a lender, involving a credit union director who obtained loans for his own private use based on false information. ${ }^{140}$ APRA's enforceable undertakings register includes an action in 2012 against a small Taiwanese bank, ${ }^{141}$ and a more recent agreement with CBA on 30 April 2018. ${ }^{142}$ The enforceable undertaking agreed with CBA followed a prudential inquiry into the bank that was announced on 28 August 2017. The Final Report of this inquiry was released in April 2018 and identified several shortcomings in CBA's governance, culture and accountability. To address these deficiencies, the Final Report made a series of recommendations. ${ }^{143}$ In accordance with section 18A of the Banking Act, CBA has undertaken to provide a remedial plan to APRA that responds to each of these recommendations, including clear timelines and specific executive responsibilities. ${ }^{144}$ It has further agreed to appoint an independent reviewer until completion of the remedial action plan, to provide a report to APRA showing how the Final Report findings have been reflected in executive remuneration outcomes, and to reflect the remedial action plan items in the relevant staff performance score cards. CBA will also increase its capital base by $\$ 1$ billion and will only apply to APRA to remove or adjust this amount when the specific undertakings and remedial action plan have been completed. ${ }^{145}$ APRA strongly defends its use of enforceable undertakings and argues that it is 'outcomes oriented' and allows for flexible remedies beyond those provided for under the relevant legislation. ${ }^{146}$ However, for enforceable undertakings to be effective in preventing risk to the financial system, they must be adequately monitored. ${ }^{147}$ APRA can seek a court order when an entity fails to comply with an enforceable undertaking, but this power has not been used to date.

Furthermore, it has been recommended in the 2019 Australian Prudential Regulation Authority Capability Review report that APRA must broaden its approach to supervision with a more in-depth and transparent focus on governance, culture and accountability in regulated entities, the prudential inquiry into CBA referred to above

140 This was the disqualification of John Leaver Throwden on 3 February 2006: 'Disqualification Register' Australian Prudential Regulation Authority (Web Page, 2019) < https://www.apra.gov.au/disqualificationregister>.

141 This undertaking with Mega International Commercial Bank Co Ltd in 2012 required an overhaul of the company's risk management and internal control systems, and a review of the suitability of the senior management in Australia: 'Enforceable Undertakings Register', Australian Prudential Regulation Authority (Web Page, 2019) <https://www.apra.gov.au/enforceable-undertakings-register>.

142 Commonwealth Bank of Australia, Enforceable Undertaking (30 April 2018).

143 Australian Prudential Regulation Authority, Prudential Inquiry into the Commonwealth Bank of Australia (Report, April 2018) 102-4. Note that the conduct on the part of CBA that led to the Inquiry consisted of a number of serious examples of misconduct between 2008 and 2018, listed at page 6 of the report as

mis-selling of margin loans to retail customers to invest in financial products recommended by Storm Financial (2008); misconduct by financial advisers in Commonwealth Financial Planning, part of CBA's wealth business (2010/11); fees for no service in financial advice (2012 to 2015); use of an outdated definition of heart attack in insurance products sold by CommInsure (2016); anti-money laundering (AML) breaches and AUSTRAC action (2017); and mis-selling of credit card insurance (2013 to 2018).

144 Commonwealth Bank of Australia (n 142) 3.

145 Ibid 2 [9], 4 [15].

146 Ben Butler, 'APRA Denies Enforceable Undertakings are a "Weak" Response', The Australian (online, 11 May 2018) <https://www.theaustralian.com.au/business/financial-services/apra-denies-enforceable-undertakings-area-weak-response/news-story/ae4c1cf1649fdd5f9514752357259ab1>. See also Australian Prudential Regulation Authority, Submission to Royal Commission into Misconduct in the Banking, Superannuation and Financial Services Industry (2018) 5.

147 Australian Prudential Regulation Authority, Submission to Royal Commission into Misconduct in the Banking, Superannuation and Financial Services Industry (n 146) 4. 
being a good example of this. ${ }^{148}$ APRA has accepted this recommendation, noting that it needs to adopt more transparent supervision and enforcement. ${ }^{149}$

There has also been a call for both of the financial regulators to litigate in order to ensure that the law is enforced, rather than seek alternative regulatory approaches, unless there are good reasons not to litigate. As Commissioner Hayne noted in his final report, the relevant question must always be “"[w] hy not litigate?"” 150

\section{FURTHER ANALYSIS AND CRITIQUE}

[M]indsets can be shaped by people you associate with, and you come to think that what's good for Wall Street is good for America. ${ }^{151}$

APRA sets general standards and provides guidance on these standards rather than prescribing certain conduct. ${ }^{152}$ APRA explains this approach as follows: 'APRA's supervision allows institutions to use a variety of approaches to comply with high-level principles, rather than APRA seeking to direct an institution through detailed prescription'. ${ }^{153}$

Some scholars suggest this approach is more effective than a 'one size fits all' approach to regulation because it allows institutions to respond to standards and outcomes in a manner best suited to their own context. ${ }^{154}$ However, '[i]t is hard to classify any one regulatory regime as being either entirely rules or principles based; the better question is what are, and should be, the relative roles of each'. ${ }^{155}$ The efficacy of any prudential framework, whether principle or rules based, depends on systematic monitoring and timely and appropriate regulatory interference when the desired standards and outcomes are not being achieved. As Byres notes, '[s]ound policies only provide comfort if they are actually followed'. ${ }^{156}$

Evidence that emerged from the Commission hearings suggests that industry compliance with APRA's broader principles and guidance was persistently poor and it has only been when APRA set specific benchmarks that home lending standards were tightened significantly. Even then, the benchmarks APRA introduced were reactive to issues that had arisen rather than being proactive attempts to avoid issues. For example, APRA only responded formally to the systemic risks posed by excessive issuance of interest-only home loans in March 2017, but it failed to comprehensively investigate the nature and scale of home loan serviceability and other compliance issues, and

148 Australian Prudential Regulation Authority Capability Review (Report, June 2019) 77-82.

149 'APRA's Response to the Capability Review Report', Australian Prudential Regulation Authority (Web Page, 2019) <https://www.apra.gov.au/apras-response-to-capability-review-report>.

150 Royal Commission into Misconduct in the Banking, Superannuation and Financial Services Industry (Final Report, February 2019) vol 1, 436 ('Royal Commission Final Report').

151 Jo Becker and Gretchen Morgenson, 'Geithner, Member and Overseer of Finance Club', The New York Times, (online, 26 April 2009) <https://www.nytimes.com/2009/04/27/business/27geithner.html>, quoting Joseph Stiglitz.

152 Australian Prudential Regulation Authority, 'Australian Prudential Regulation Authority: Protecting Australia's Depositors, Insurance Policyholders and Superannuation Fund Members’ (Brochure) 7.

153 Ibid.

154 See discussion in Michael Barr, 'Credit Where It Counts: The Community Reinvestment Act and Its Critics' (2005) 80(2) New York University Law Review 513.

155 Julia Black, 'The Rise, Fall and Fate of Principles-Based Regulation' in Kern Alexander and Niamh Moloney (eds), Law Reform and Financial Markets (Edward Elgar, 2011) 3, 33. See also Julia Black, 'Forms and Paradoxes of Principles-Based Regulation' (2009) 3(4) Capital Markets Law Journal 425.

156 Byres, 'Housing: The Importance of Solid Foundations' (n 1). 
APRA's focus on LTI and debt-to-income standards only emerged in late 2017 and early 2018 respectively.

APRA confirms that its supervisory responses can range from a normal cycle of review to heightened supervisory oversights, to mandating improvements, or to restructuring a supervised entity. ${ }^{157}$ This layered regulatory approach is consistent with the enforcement pyramid theory developed by Ayres and Braithwaite in the early 1990s. ${ }^{158}$ This theory suggests that for regulation to be effective, supervisors should respond to regulatees on a tiered basis, moving from light touch interventions to more severe interventionist actions. Regulators must be prepared to respond more severely when required, in order to demonstrate that the threat of more stringent action is real. However, the only evidence we found of a credible threat to the major lenders was the action taken against CBA in mid-2017. Thus, APRA barely used its available powers and regulatory muscle, even when the governance, risk management, and residential property lending standards of ADIs fell well short of its prudential standards and guidance.

APRA has publicly stated that it prefers to resolve issues and concerns cooperatively. ${ }^{159}$ This mindset may explain why APRA only used its legal powers as a last resort or not at all during the study period, even when entities were not fully cooperating, or when necessary to protect the broader long term national interests. ${ }^{160}$ In 2018, Byres indicated that he '[has] been ... engaged in ... a tug of war with the [banking] industry, to try to improve standards [in the mortgage lending industry]'. ${ }^{161}$ In October 2017, he admitted that competitive pressures had pushed lenders towards the 'lowest common denominator' and this had resulted in a widespread deterioration in mortgage lending standards in Australia. ${ }^{162}$ These comments suggest the APRA leadership failed to use its weight and power sufficiently to ensure the prudential standards were complied with and to adequately prepare Australia for the next financial crisis.

APRA benchmarks its performance against key performance indicators ('KPI'), and the third KPI that it uses states that actions undertaken by regulators are proportionate to the regulatory risk being managed. ${ }^{163}$ In outlining its positive performance against this KPI, APRA quotes feedback from an industry association that indicated that 'APRA has adopted a sophisticated yet sensible risk-based approach that both recognises the importance of retaining and enhancing competition and choice, and not unnecessarily impeded the efficient operation of regulated entities'. ${ }^{164}$

What is concerning about this is the fact that APRA's assessment of its own performance relies on comments by those it is regulating, which suggests that its cooperative approach is primarily aligned with the interests of industry.

157 Australian Prudential Regulation Authority, The APRA Supervision Blueprint (Report, May 2015) 10.

158 Ian Ayres and John Braithwaite, Responsive Regulation: Transcending the Regulation Debate (Oxford University Press, 1992) 25.

159 Australian Prudential Regulation Authority, 'Layers of Safety' (n 20) 1.

160 Ibid.

161 Evidence to House Standing Committee on Economics, Parliament of Australia, Canberra, 28 March 2018, 3 (Wayne Byres).

162 Wayne Byres, 'Individual Challenges and Mutual Opportunities' (Speech, Customer Owned Banking Convention, 23 October 2017).

163 See Australian Prudential Regulation Authority, APRA Regulator Performance Framework: 1 July 2016 - 30 June 2017 Self-Assessment (Report, 2017) 3-6, 17.

164 Ibid 21. 
Regulatory theories commonly highlight regulatory capture as a significant impediment to effective supervision of prudential and financial stability frameworks. ${ }^{165}$ Regulatory capture arises when banks exert influence that causes regulators to act primarily in the interests of industry rather than in the public or national interest. ${ }^{166}$ The potential for regulatory capture is acute in the finance sector, ${ }^{167}$ driven by information asymmetries and externalities. ${ }^{168}$ The size and political power of the largest financial institutions in Australia and globally are comparable to some nation states, and these companies operate, in effect, as an oligopoly. ${ }^{169}$ The resources and power of these corporations allow them to actively lobby and influence the supervisory processes, as well as the broader policy debates. ${ }^{170}$ Global empirical studies suggest that finance entities that were the most active lobbyists prior to a financial crisis increased their level of risk taking, received a greater amount of bailout funds, and limited the likelihood of enforcement action. ${ }^{171}$ The fact that financial institutions are in many respects providing a quasi-public service has arguably enabled them to avoid regulatory consequences, on the basis of a perception that financial stability was best served by protecting those institutions. ${ }^{172}$

At an operational level, bank supervisors and regulators are in close contact with the institutions they oversee and need their cooperation. ${ }^{173}$ Regulators naturally want to identify and work smoothly with those they are working with and supervising on a daily basis. ${ }^{174}$ Additionally, as occurs in many professional areas, regulators tend to value

165 See discussion in Bronwen Morgan and Karen Yeung, An Introduction to Law and Regulation: Texts and Materials (Cambridge University Press, 2007) 61-2; Robert Baldwin and Martin Cave, Understanding Regulation: Theory, Strategy and Practice (Oxford University Press, Oxford, 1999) 43-9.

166 George J Stigler, 'The Theory of Economics Regulation' (1971) 2(1) The Bell Journal of Economics and Management Science 3. Stigler argues in his seminal article that regulatory and supervisory agencies tend to respond to the wishes of the industry they regulate and supervise, particularly the best organised interest groups. See also Deniz Igan and Thomas Lambert, 'Bank Lobbying: Regulatory Capture and Beyond' in Emilios Avgouleas and David C Donald (eds), The Political Economy of Financial Regulation (Cambridge University Press, 2019) 129. But see Lawrence G Baxter, "Capture" in Financial Regulation: Can We Channel It Toward the Common Good?' (2011) 21(1) Cornell Journal of Law \& Public Policy 175, 176-88. Baxter discusses the complexities of defining regulatory capture and the different forms of capture including visible capture and deeper cultural capture.

167 Canova (n 113) 380; Adam J Levitin, 'The Politics of Financial Regulation and the Regulation of Financial Politics: A Review Essay’ (2014) 127(7) Harvard Law Review 1991, 2041-9. See also Daniel C Hardy, 'Regulatory Capture in Banking' (Working Paper No WP/06/34, International Monetary Fund, January 2006).

168 Igan and Lambert (n 166) 139-43.

169 Baxter (n 166) 192. See also Australian Government Productivity Commission, Competition in the Australian Financial System (n 26) 4, 57-8.

170 Igan and Lambert (n 166); Thomas Lambert, 'Lobbying on Regulatory Enforcement Actions: Evidence from US Commercial and Savings Banks' (2018) 65(6) Management Science 2545; Deniz Igan, Prachi Mishra and Tthierry Tressel, 'A Fistful of Dollars: Lobbying and the Financial Crisis (2012) 26(1) National Bureau of Economic Research Macroeconomics Annual 195. See Levitin (n 167) 2044-5; Canova (n 113) 384. See also Colin Crouch, The Strange Non-Death of Neoliberalism (Polity Press, 2011) 2.

171 Igan and Lambert (n 166); Lambert (n 170); Igan, Mishra and Tressel (n 170). See Levitin (n 167) 2023-9; Canova (n 113) 384-5.

172 Andrew Schmulow, Karen Fairweather and John Tarrant, 'Restoring Confidence in Consumer Financial Protection Regulation in Australia: A Sisyphean Task?' (2019) 47(1) Federal Law Review 91, 95, 101.

173 Levitin, (n 167) 2041-9; Baxter, (n 166) 184-7.

174 Evidence to Subcommittee on Financial Institutions and Consumer Protection, US Senate Committee on Banking, Housing and Urban Affairs, United States Congress, Washington DC, 21 November 2014, 65 (Robert Hockett) ('Robert Hockett Evidence to Subcommittee on Financial Institutions and Consumer Protection'). See also Baxter (n 166) 184-7; James Kwak, 'Cultural Capture and the Financial Crisis' in Daniel Carpenter and David A Moss (eds), Preventing Regulatory Capture: Special Interest Influence and How to Limit It (Cambridge University Press, 2014) 71, 81-5, 89-93. 
status and power, and want to align with the right social, economic, and intellectual circles. ${ }^{175}$ These tendencies make it difficult for regulators to remain independent, question the status quo and maintain a sceptical and conservative stance during boom times. ${ }^{176}$ Importantly, the negative effects of regulatory capture are often most severe when there are conflicts between the profit interests of financial institutions and the financial stability and consumer protection goals of regulators and supervisors. ${ }^{177}$

An important factor that increases the level of regulatory capture is a 'revolving door syndrome' that occurs when personnel move back and forth between executive positions in the private sector and supervisory positions in the regulatory sector. Empirical works suggests this syndrome significantly impedes the independence of regulators. ${ }^{178}$ One study of financial supervisors found that regulators with prior tenure in industry were more likely to socially identify with the financial sector and this negatively affected their supervisory performance. ${ }^{179}$ Other studies found that supervisors with previous industry experience were more supportive of industry and were more likely to be lenient. ${ }^{180}$ These findings are relevant to assessment of APRA's performance, as six of the nine executives running APRA come from senior executive positions in industry. ${ }^{181}$

The long period of credit and economic growth in Australia, APRA's cooperative supervisory approach, and a leadership team dominated by prior industry executives would have made it difficult for APRA to establish stronger countercyclical policies and resist political pressures from industry and others. ${ }^{182}$ APRA's response to criticism during the first week of Commission hearings is revealing. Byres indicated that the 'bad bank behaviour' that had been exposed was primarily the responsibility of ASIC. ${ }^{183} \mathrm{He}$ acknowledged that APRA had a 'prudential interest in these issues' but indicated that he was still 'trying to understand the extent to which these issues indicate a failing in

175 Baxter (n 166) 184; Kwak (n 174) 85-9; Jon Hanson and David Yosifon, 'The Situation: An Introduction to the Situational Character, Critical Realism, Power Economics, and Deep Capture' (2003) 152(1) University of Pennsylvania Law Review 129, 202-84; Dennis Veltrop and Jakob de Haan, 'I Just Cannot Get You Out of my Head: Regulatory Capture of Financial Sector Supervisors' (Working Paper No 410, De Nederlandsche Bank, January 2014).

176 Robert Hockett Evidence to Subcommittee on Financial Institutions and Consumer Protection (n 174) 65-6. See also Baxter, (n 166) 189; Geoffrey P Miller and Gerald Rosenfeld, 'Intellectual Hazard: How Conceptual Biases in Complex Organizations Contributed to the Crisis of 2008' (2010) 33(2) Harvard Journal of Law and Public Policy 807, 816; Veltrop and de Haan, (n 175) 7.

177 Benink and Schmidt (n 20) 186.

178 Baxter (n 166) 197; Canova (n 113) 384. Canova describes the revolving door tendency in the United States as 'incestuous' and suggests these practices result in policy that '[reflects] the bargain ... between the most powerful private interests'.

179 Veltrop and de Haan (n 175) 4, 8-9.

180 Jeffrey E Cohen, 'The Dynamics of the "Revolving Door” on the FCC' (1986) 30(4) American Journal of Political Science 689; Ernesto Dal Bó, 'Regulatory Capture: A Review' (2006) 22(2) Oxford Review of Economics Policy 203.

181 Anthony Klan, “APRA "Captured by Major Banks"', The Australian (Canberra, 23 July 2018) 8.

182 As Jane Diplock suggested in the wake of the GFC, when everybody appears to be making money, and there's exuberance in the markets, it's extremely difficult to be the Jeremiah saying: 'Look, that's a cliff you're about to run over'. Nobody wants to hear that message, least of all [those] ... whose funds are perhaps being swollen by the very people making all this money.

Australian Securities and Investments Commission, Securities and Investment Regulation: Beyond the Crisis (Report, 1-3 March 2010) 76.

183 Roddan (n 58). See generally Creighton (n 21) 16. 
the governance [oversights]' in banks. ${ }^{184}$ This muted and vague response suggests astonishing complacency by APRA and is at least some indication of regulatory capture.

In a self-assessment of its actions to prepare Australia for a rainy day, APRA argues that the finance sector is sufficiently capitalised for extreme events. ${ }^{185}$ Increases in the capital holdings of Australian financial institutions over the last decade have undoubtedly improved their resilience and reduced some of the systemic risks. Nevertheless, APRA's claims regarding its effective supervision of capital levels are challengeable on several fronts. First, the proposed changes to APS 112 should have been implemented earlier to prevent or moderate high-risk lending practices, ${ }^{186}$ including inappropriate use of interest-only home loans, investment home loans and small business loans secured on residential property, and the issuance of home loans outside of the serviceability benchmarks and affordability obligations. Second, the capital adequacy of the sector in the worst case scenario posited by APRA in its stress tests is strongly refuted by some economists. ${ }^{187}$ Third, regardless of who is proved right on the capital adequacy question, a primary focus on capital levels is responding to the most acute symptoms of the financial system rather than its long-term health. ${ }^{188}$ As Coen, the Secretary-General of the Basel Committee has indicated, when 'it comes to safe, resilient banks and banking systems, strong capital is only one factor ... [and] [e]xclusive focus on capital is too narrow and misses the big picture'. ${ }^{189}$ To ensure lasting financial stability, it was critical for APRA to ensure that the broader governance and risk structures of all lenders remained prudent and fit for purpose. But, excepting the action against CBA, this regulatory strand appears to have been largely ignored by the APRA leadership.

APRA has sought to demonstrate the effectiveness of its formal guidance to ADIs and has described its actions as 'modest' and 'orderly'. ${ }^{190}$ In its self-assessment report, APRA highlights the slowdown in the rate of growth of new investment and interestonly home loans following the relevant guidance. However, these loans continued to be issued and the overall share of these riskier loans remains high. Byres described the $40 \%$ share of interest-only loans in March 2017 as 'quite high by international and historical standards', ${ }^{191}$ but this characterisation is understated. ${ }^{192}$ Other high-risk home

184 Roddan (n 58), quoting Wayne Byres.

185 Wayne Byres, 'Preparing for a Rainy Day' (Speech, Australian Business Economists, 11 July 2018).

186 Byres, 'Remarks for "The Regulators" Panel' (n 32). Byres indicates that APRA held off on responding to the Financial Inquiry recommendation for unquestionably strong capital standards until the Basel international capital standards had been completed.

187 See, eg, 'Putting APRA's Stress to the Test' (n 116); Adams (n 116).

188 Levitin (n 167) 2036.

189 James Eyers and Joanne Grey, 'Basel's Bill Coen Says Bank Strength Extends Beyond Capital Buffers', The Sydney Morning Herald (online, 4 April 2016) <https://www.smh.com.au/business/banking-and-finance/baselscoen-says-bank-strength-extends-beyond-capital-buffers-20160404-gnxtqd.html>.

190 Byres, 'Preparing for a Rainy Day' (n 185).

191 Australian Prudential Regulation Authority, 'APRA Announces Further Measures to Reinforce Sound Residential Mortgage Lending Practices’ (Media Release, 31 March 2017) <https://www.apra.gov.au/news-andpublications/apra-announces-further-measures-to-reinforce-sound-residential-mortgage $>$. See also Australian Prudential Regulation Authority, Statistics: Quarterly Authorised Deposit-Taking Institution Property Exposures (n 49) Table 1b: ADIs' Residential Property Exposures.

192 See Financial Conduct Authority, The Fair Treatment of Existing Interest-Only Mortgage Customers (Thematic Review No TR18/1, January 2018). See also Sharon R Smyth, 'UK Homeowners with Interest-Only Loans Risk Losing Properties', Bloomberg (online, 30 January 2018) < https://www.bloomberg.com/news/articles/2018-0130/u-k-homeowners-with-interest-only-loans-risk-losing-properties $>$. 
loans include those issued with high LTI and debt-to-income ratios, ${ }^{193}$ but APRA did not formally address these forms of lending until April 2018. ${ }^{194}$ Indeed, during most of the study period, APRA failed to collect either LTI or debt-to-income data from lenders, so was unable to respond quickly and informedly to the associated systemic risks. Finally, when discussing high-risk home lending, it is important to highlight the lack of proactive and thorough supervision by APRA during the study period of non-ADI lenders. ${ }^{195}$ Byres confirms that 'there are clearly some individual non ADIs with lending portfolios that are dominated by the sorts of lending that we have been disincentivising ADIs from taking on' ${ }^{196}$ But surprisingly, he describes new legislative powers given to APRA to monitor non-ADI lenders as' very much a reserve power'. ${ }^{197}$ Byres confirms that APRA will not be undertaking any supervision of individual lenders and is keen to distance itself from any perception that APRA is responsible for the activities of these lenders. ${ }^{198}$ APRA's failure to collect reliable data on lending by non-ADIs and to consider and engage with the systemic impact and riskiness of these loans is likely to emerge as a significant risk factor when the financial environment deteriorates.

In the context of responsible lending requirements, some regulatory regimes have sought to emphasise responsible borrowing over responsible lending ${ }^{199}$ given that it is not unreasonable to expect consumers to assume some responsibility for their financial decisions. ${ }^{200}$ At the same time, there does need to be some acknowledgment of the market realities including imbalances of power, risk and information between lenders and borrowers, and borrower limitations and behavioural biases. ${ }^{201}$ Byres acknowledges these realities and confirms that 'lenders know that borrowers have difficulty estimating their expenses (and have an incentive to understate them)' ${ }^{202}$ Given this knowledge of borrower behaviour, it was essential for APRA to proactively ensure that all lenders were obtaining and independently verifying the accuracy and credibility of home loan

193 'Insights from Dynamic Loan to Income', Digital Finance Analytics (Blog Post, 10 November 2017) $<$ https://digitalfinanceanalytics.com/blog/insights-from-dynamic-loan-to-income/ $>$.

194 Byres, 'Housing: The Importance of Solid Foundations' (n 1).

195 See, eg, Alan Kohler, 'Australia's Shadow Banking Ponzi Scheme’, The Australian (online, 26 May 2018) $<$ https://www.theaustralian.com.au/business/australias-shadow-banking-ponzi-scheme/newsstory/9401ce0e46f4bebf34eef9e467f2fa50>; Cliona O’Dowd, 'UBS Raises Alarm Over "Shadow Banks" as Lending Clamps Tighten in Big Four’, The Australian (online, 6 July 2018)

$<$ https://www.theaustralian.com.au/business/financial-services/ubs-raises-alarm-over-shadow-banks-as-lendingclamps-tighten-on-big-four/news-story/c0364590ceebb8c537f2d9a12d70d820>.

196 Byres, 'Housing: The Importance of Solid Foundations' (n 1).

197 Ibid.

198 Ibid.

199 See, eg, Alan Schwartz, 'Unconscionability and Imperfect Information: A Research Agenda' (1991) 19(1) Canadian Business Law Journal 437, 444-9; Geoffrey Christopher Rapp, 'The Wreckage of Recklessness' (2008) 86(1) Washington University Law Review 111; John AE Pottow, 'Private Liability for Reckless Consumer Lending' [2007] (1) University of Illinois Law Review 405; Therese Wilson, 'The Responsible Lending Response' in Therese Wilson (ed), International Responses to Issues of Credit and Over-indebtedness in the Wake of Crisis (Ashgate, 2013) 109.

200 James Thomson, 'APRA Chairman Wayne Byres' Timely Reminder on Caveat Emptor', Australian Financial Review, (online, 18 July 2018) <https://www.afr.com/brand/chanticleer/apra-chairman-wayne-byres-timelyreminder-on-caveat-emptor-20180711-h12jpk>.

201 Ibid. See also Iain Ramsay, 'Consumer Credit Law, Distributive Justice and the Welfare State' (1992) 15(2) Oxford Journal of Legal Studies 177; Oren Bar-Gill and Elizabeth Warren, 'Making Credit Safer' (2008) 157(1) University of Pennsylvania Law Review 1; Gill North, ‘A Consumer's Perspective’ (n 31); North and Wilson (n10).

202 Byres, 'Housing: The Importance of Solid Foundations' (n 1). 
borrowers' income and expenses information, as required under the $N C C P .{ }^{203}$ Yet, it was not until 2018 that lenders began to consistently obtain and verify home loan borrowers' expense data.

The overall serviceability, affordability and legality of outstanding home loans in Australia remains uncertain, but current evidence signals major underlying issues. Notably, a commissioned report that reviewed 418 mortgage applications found 33\% had errors and $16 \%$ had incomplete or incorrect borrower information. ${ }^{204}$ Byres indicated to the Senate in late 2017 that he was not aware of any fraud occurring in the finance sector. ${ }^{205}$ If this was true, one is compelled to ask why not, given: (1) the major loan serviceability issues identified by APRA; (2) the reported findings in the ASIC review of interest-only home lending; and (3) the scale and seriousness of lending misconduct highlighted by the Commission. The findings from these sources were broadly consistent and revealed serious system-wide concerns with residential property lending standards. These issues included inappropriate use of higher risk investment and interest-only home loans, failures to obtain reliable data from borrowers and elsewhere to reasonably assess the serviceability and affordability of loans, failures to verify data provided by borrowers and or intermediaries such as mortgage brokers, and more egregious forms of institutional and professional misconduct. Many of these concerns were apparently ignored by APRA despite the serious risks and illegalities involved.

Broader domestic factors that are likely to have influenced APRA's responses and culture during the study period include the economic, political and regulatory perspectives of other participants on the Council of Financial Regulators ('Council'). The Council was established as a coordinating body and includes representatives from the Reserve Bank of Australia, APRA, ASIC and the Treasury Department. ${ }^{206}$ The Council is intended to operate as an overarching body for regulators to consult, share information, and discuss concerns that arise. This body is also intended to mitigate issues such as replication and poor coordination between bodies and potential gaps in the supervision and management of the broader financial system and economy. ${ }^{207}$ Byres confirmed in June 2017 that housing risks had been a big issue on the Council's agenda, ${ }^{208}$ suggesting some form of consensus may have been reached regarding APRA's approach and interventions. If so, this raises wider concerns with the Australian regulatory structure and responses.

203 For a summary outline of these rules, see North and Wilson (n 10).

204 Jonathan Mott et al, 'Could the Royal Commission Cause a Credit Crunch?' (UBS Equities Report, 22 March 2018) 1. Mott et al refer to a KPMG report commissioned by ANZ.

205 Martin North, 'The Gems in Wayne Byers Opening Statement', Digital Finance Analytics Blog (Blog Post, 28 March 2018) <https://digitalfinanceanalytics.com/blog/the-gems-in-wayne-byers-opening-statement/>.

206 See 'Welcome to the Council of Financial Regulators', Council of Financial Regulators (Web Page, 2017) $<$ https://www.cfr.gov.au/>.

207 Andrew Godwin, Steve Kourabas and Ian Ramsay, 'Twin Peaks and Financial Regulation: The Challenge of Increasing Regulatory Overlap and Expanding Responsibilities' (2016) 49(3) International Lawyer 273, $282-95$.

208 Nathan Lynch, 'Alarm Bells Are Ringing - Finally - at APRA', Macro Business (online, 1 June 2017) $<$ https://www.macrobusiness.com.au/2017/06/alarm-bells-ringing-finally-apra/>. See also Australian Prudential Regulation Authority, 'APRA Announces Plans to Remove Investor Lending Benchmark and Embed Better Practices' (n 87). 


\section{CONCLUSION}

[W]e see our role - in simple terms, seeking to make sure lenders continue to make sound loans to borrowers who can afford to pay them back - as really pretty basic bank supervision. ${ }^{209}$

The primary aim of prudential regulatory frameworks is to ensure effective management of risk within financial institutions and across financial systems, and to limit disruption and consequential damages to the economy and community. In Australia, careful management of the standards and risks associated with residential property lending is critical to achieve these aims. The proclivities of lenders to expand the provision of credit to drive activity and profits during boom times and the corresponding temptation to reduce lending standards are well documented and understood, ${ }^{210}$ as are the broader links between lending standards and financial cycles..$^{211}$ Imprudent and irresponsible home lending can deplete the capital of lenders, put creditors at risk, push borrowers into financial stress (or foreclosure and bankruptcy in worst case scenarios), and cause immense second order damages to the financial system, economy, and broader community. These second order consequences can include economic downturns that typically accompany financial crises, higher unemployment, reductions in the value of investment assets, reduced savings, lower consumption, and significant falls in business and consumer confidence. ${ }^{212}$

APRA acknowledges that its role is to prepare Australia for periods of financial stress and describes its actions during the study period as 'modest' and 'orderly'. ${ }^{213}$ While a full assessment of the efficacy of APRA's oversight can only be done in the wake of the next financial crisis, there is a risk that APRA's regulatory approach may have been 'too little, too late'. The Final Report into CBA's conduct concluded that 'a widespread sense of complacency has run through CBA, from the top down ... CBA has been reactive - rather than proactive and pre-emptive - in dealing with risks ... [and] CBA became insular. It did not reflect on and learn from experience and mistakes (its own and others')'. ${ }^{214}$ The same criticisms can be made of APRA. Our study and analysis suggest that APRA has failed to systematically monitor the outcomes of its principles-based regulation and has been reluctant to enforce its own policy settings even when lending conduct was egregious. More specifically, APRA has failed to proactively monitor compliance with its prudential standards and written guidance and failed to utilise most of its forensic and enforcement powers when the governance, risk management and lending practices of ADIs and other lenders within its mandate were

209 Francesca Krakue, 'Bank Changes Serviceability Requirements', The Adviser (online, 14 February 2017) $<$ https://www.theadviser.com.au/breaking-news/35723-bank-changes-serviceability-requirements $>$, quoting Wayne Byres, 'Remarks for "The Regulators" Panel' (Speech, A50 Australian Economic Forum, 10 February 2017).

210 See, eg, Hyman P Minsky, 'A Theory of Systematic Fragility' in Edward I Altman and Arnold W Sametz (eds), Financial Crises: Institutions and Markets in a Fragile Environment (John Wiley \& Sons, 1977); Hyman P Minsky and Mark D Vaughan 'Debt and Business Cycles' (1990) 25(3) Business Economics 23. See also Christopher Crowe et al, Macrofinancial Linkages: Trends, Crises, and Policies (International Monetary Fund, 2010); The Joint Forum, Bank for International Settlements, Developments in Credit Risk Management Across Sectors: Current Practices and Recommendations (Report, June 2015).

211 Gill North, 'A Consumer's Perspective' (n 31).

212 See, eg, Murray Report (n 104) 33, 43-4, 47.

213 Byres, 'Preparing for a Rainy Day' (n 185).

214 Australian Prudential Regulation Authority, Prudential Inquiry into the Commonwealth Bank of Australia (n 143) 4 . 
substandard or non-compliant. Poor governance and risk management processes, lax, imprudent and irresponsible home lending standards, and actual or possible breaches of the law, should have attracted immediate and stronger responses by APRA. As noted in the Commission's Final Report, ${ }^{215}$ given the significance of APRA's work to the strength of Australia's financial system, APRA itself should be 'subject to more consistent and rigorous assessment' including a management accountability regime such as that it now oversees with respect to financial institutions under the Banking Executive Accountability Regime ('BEAR'). ${ }^{216}$ This recommendation was repeated in the APRA Capability Review report which noted that APRA should be held to its mandate by an oversight authority, as part of an external accountability framework. ${ }^{217}$ As noted recently by Schmulow, Fairweather and Tarrant, such oversight can provide an important role not only in preventing mis-use of power but also 'under-use of power [as a result] ... of regulatory capture' ${ }^{218}$

The largest banks in Australia and elsewhere operate as financial conglomerates, with vertically integrated structures that operate with deeply entrenched institutional and sectoral risks. Moreover, the world of finance is increasingly interconnected across the globe and the Bank for International Settlements has reportedly indicated that ' $[\mathrm{t}] \mathrm{he}$ global economy is caught in a permanent trap of boom-bust financial cycles, a deformed structure becoming ever more corrosive and dangerous as debt ratios rise to nosebleed levels'. ${ }^{219}$ Australia is especially vulnerable within this environment, given the domination of home loans in our credit markets, the excessive use of riskier forms of home loans over the last decade, our economic reliance on housing construction, and the vulnerability of many borrowers.

APRA claims that its role, in simple terms, is to ensure lenders make sound loans to borrowers who can afford to pay them back and describes this as basic bank supervision. ${ }^{220}$ However, this article has raised concerns about the effectiveness of APRA's approach, at least in the period leading up to the Commission hearings and report. The capacity of the Australian government, supervisory bodies and borrowers to cope with negative events and circumstances, such as rising interest rates, deteriorating economic conditions, or systemic shocks, may have been compromised. As Byres notes, '[i]t is easy to run up debt, but far harder to pay it back down when circumstances change'. ${ }^{221}$ Nearly 20 years ago, the Royal Commission into the Failure of HIH Insurance found that APRA did not recognise the seriousness of the situation or question the reliability of the information it was receiving. ${ }^{22}$ The same criticisms could be made of APRA during the study period. APRA did not question or verify the data provided by financial institutions, seek to capture granular data on the level and distribution of debt in Australia and the capacity of borrowers to repay in deteriorating circumstances,

215 Royal Commission Final Report (n 150) 476.

216 The BEAR focuses on improved accountability of 'accountable individuals' within banks, to ensure a sound risk culture and effective corporate governance. The Commission's Final Report recommended that both APRA and ASIC should also be subject to this type of accountability regime: Royal Commission Final Report (n 150) 39.

217 Australian Prudential Regulation Authority Capability Review (n 148) 129.

218 Schmulow, Fairweather and Tarrant (n 172) 104.

219 Ambrose Evans-Pritchard, "Next Financial Crisis to Hit with a "Vengeance", The Sydney Morning Herald (online, 26 June 2018) <https://www.smh.com.au/business/the-economy/next-financial-crisis-to-hit-with-avengeance-20170626-gwycr6.html>.

220 Byres, 'Remarks for "The Regulators" Panel' (n 32).

221 Byres, 'Housing: The Importance of Solid Foundations' (n 1).

222 Royal Commission into the Failure of HIH Insurance (Final Report, April 2003) vol 3, ch 24.1-24.2. 
or adequately forewarn the sector, policy makers, and the community of the mounting systemic risks.

To create lasting financial stability in Australia (and elsewhere) will require significant reforms of the politics of financial regulation, including the policies, supervision and independence of regulators such as APRA. ${ }^{223}$ Financial stability frameworks that focus predominantly on industry and capital adequacy concerns are likely to prove largely ineffective, or even counterproductive. ${ }^{224}$ To prevent or constrain much of the harm arising from financial crises, regulatory structures need to be driven by public good and national interest considerations, including the interests of the most vulnerable communities.

APRA's role as supervisor of ADIs under the BEAR is informed by the idea that a sound risk culture, effective corporate governance and strong consequences will improve accountability and performance. APRA has noted the need for individual responsibilities within an organisation to be well understood to ensure clear accountability and consequences for failure on the part of individuals in the organisation to meet their obligations.225 The Commission's Final Report made clear that APRA and ASIC should also be subject to such a regime, and should internally formulate and apply to [their] own management accountability principles of the kind established by the BEAR'. ${ }^{226}$ The Report also recommended that APRA and ASIC be subject to 'at least quadrennial capability reviews' to ensure that their 'structure and processes remain appropriately adapted to market conditions', and that there be established a permanent oversight body for both APRA and ASIC. ${ }^{227}$ The Report also noted that APRA itself had recognised that its approach to enforcement has to change moving into the future..$^{228}$

These are all positive suggestions moving towards greater accountability by APRA as regulator in its role of protecting financial stability. The financial resources and political power of the finance sector are immense and can be used to unduly influence policy developments and the extent and way in which existing regulation is supervised and enforced. As the Commission has highlighted, there is a current lack of public trust in financial institutions which, in order to be restored, will require both those institutions, and the institutions that regulate them including APRA, to prioritise community interest.

223 Levitin (n 167) 2054-8. See also Baxter (n 166) 188, 191-2, 200. Baxter states that '[w]e must do something to try to counteract the massive dominance of the financial industry in our public life'. He notes that one of the factors that creates a climate ripe for capture is the exclusion of important stakeholders such as consumers, taxpayers and other diffuse interests from the policymaking processes.

224 Levitin (n 167) 2035-7; Gill North, 'A Consumer's Perspective' (n 31).

225 Australian Prudential Regulation Authority, Implementing the Banking Executive Accountability Regime (Information Paper, 17 October 2018) 6-7.

226 Royal Commission Final Report (n 150) 40, 470.

227 Ibid 471-80.

228 Ibid 480 